\title{
The Impact of COVID-19 Pandemic on Female Sexual Behavior
}

\section{COVID-19 Salgınının Kadın Cinsel Davranışına Etkisi}

\author{
(D) Evrim Ebru Kovalak, (D Özlem Karabay Akgül, (D) Tolga Karacan, (D) Özlem Yüksel Aybek, \\ (D) Hakan Güraslan
}

University of Health Sciences Turkey, İstanbul Bağcllar Training and Research Hospital, Clinic of Obstetrics and Gynecology, İstanbul, Turkey

\section{Abstract}

Objective: The Coronavirus disease-2019 (COVID-19) related isolation has resulted in economic damage, loneliness, fear of death, and depression all around the world. Self-isolation and social distance lead to unintended psychological effects and negatively affect sexual life. This study aimed to investigate women's sexual behavior during the COVID-19 pandemic in our country.

Method: This prospective, observational study was conducted in a tertiary referral hospital between June 27 and July 27,2020. A questionnaire consisting of 13 questions regarding the sexual life during the COVID-19 pandemic was applied to 169 women aged 18-45 years. Demographic characteristics were recorded. The questions evaluating sexual behavior about the relationship with partner, sexual desire, frequency of intercourse, sexual satisfaction, and fertility desire were asked.

Results: The mean age of the participants was $32.9 \pm 7.74$ years (1845). Regarding the per capita monthly income, 84 (60\%) patients had a decrease, $53(37.9 \%)$ of them remained stable, and only $3(2.1 \%)$ of them had an increase during the pandemic. Sexual desire was decreased by $32.9 \%$ of the participants and remained the same in $58.6 \%$ of the participants. A higher rate of $40.5 \%$ was observed in the decreased group than in the stable income group with $22.7 \%(p=0.03)$. A statistically significant difference was found between the decrease in sexual desire rates. However, when the change in income level of the groups and their sexual satisfaction rates were compared, it was found that sexual satisfaction increased in those with a lower income level, and the difference was statistically significant $(p=0.04)$.

Conclusion: Acute stress caused by the COVID-19 pandemic negatively affected sexuality. The decreased income level reduces sexual desire, but we observed an increase in sexual satisfaction rates in this group.

Keywords: Coronavirus, COVID-19, pandemic, sexual behavior, sexual function

\section{öz}

Amaç: Koronavirüs hastalığı-2019 (COVID-19) ile ilişkili izolasyon tüm dünyada ekonomik hasar, yalnızlık, ölüm korkusu ve depresyon ile sonuçlandı. Kendini izole etme ve sosyal mesafe, istenmeyen psikolojik etkilere neden olur ve cinsel yaşamı da olumsuz etkiler. Bu çalışma, ülkemizde COVID-19 salgını sırasında kadınların cinsel davranışlarını incelemeyi amaçlamaktadır.

Yöntem: Bu prospektif, gözlemsel çalışma, 27 Haziran-27 Temmuz 2020 tarihleri arasında üçüncü basamak bir hastanede gerçekleştirildi. COVID-19 salgını sırasında cinsel yaşam ile ilgili 13 sorudan oluşan bir anket, 18-45 yaş arasındaki 169 kadına uygulandı. Demografik özellikler kaydedildi. Partnerle ilişki, cinsel istek, ilişki sıklığı, cinsel doyum, doğurganlık isteği gibi cinsel davranışları değerlendiren sorular soruldu.

Bulgular: Katılımcıların ortalama yaşı 32,9 $\pm 7,74$ (18-45) idi. Pandemi sırasında, aylık gelirin 84 (\%60) hastada azaldığı, 53 (\%37,9) hastada aynı kaldığı, sadece $3(\% 2,1)$ hastada arttığı görüldü. Katılımcıların \%32,9'unda cinsel istek azalırken, \%58,6'sında aynı kaldı. Geliri azalan grupta cinsel istekte azalma $(\% 40,5)$, geliri değişmeyen gruba $(\% 22,7)$ göre daha yüksek idi. Cinsel istek oranlarındaki azalma arasında istatistiksel olarak anlamlı bir fark bulundu $(p=0,03)$. Ancak grupların gelir düzeyi değişikliği ile cinsel doyum oranları karşılaştırıldığında ise gelir düzeyi azalanlarda cinsel doyumun arttığı, farkın ise istatistiksel olarak anlamlı olduğu bulundu $(p=0,04)$.

Sonuç: COVID-19 salgınının neden olduğu akut stres, cinselliği olumsuz etkilemiştir. Azalan gelir düzeyi cinsel isteği azaltır, ancak bizim çalışmamızda bu grupta cinsel doyum oranlarında artış gözlemlenmiştir.

Anahtar kelimeler: Cinsel davranış, cinsel işlev, COVID-19, koronavirüs, salgın

Address for Correspondence: Evrim Ebru Kovalak, University of Health Sciences Turkey, İstanbul Bağcılar Training and Research Hospital, Clinic of Obstetrics and Gynecology, İstanbul, Turkey

E-mail: evrimebru@yahoo.com ORCID: orcid.org/0000-0001-5311-1060 Received: 21.03.2021 Accepted: 18.07.2021

Cite this article as: Kovalak EE, Karabay Akgül Ö, Karacan T, Aybek ÖY, Güraslan H. The Impact of COVID-19 Pandemic on Female Sexual Behavior. Bagcilar Med Bull 2021;6(3):271-275

${ }^{\circ}$ Copyright 2021 by the Health Sciences University Turkey, Bagcilar Training and Research Hospital Bagcilar Medical Bulletin published by Galenos Publishing House. 


\section{Introduction}

COVID-19 is a contagious disease caused by severe acute respiratory syndrome-coronavirus-2 (SARS-CoV-2), a new type of coronavirus. World Health Organization (WHO) first declared the presence of the virus on December 31 , 2019, following spreading viral pneumonia cases in Wuhan, China. WHO declared the COVID-19 outbreak as a pandemic on March 11, 2020 (1).

SARS-CoV-2 is RNA virus that primarily affects the respiratory system and is transmitted by large respiratory droplets or direct contact. It can be fatal by causing pneumonia, bronchitis, and SARS $(2,3)$. At the time of writing this study, 80,805,661 people were infected, and $1,766,726$ people died because of the disease worldwide. Moreover, borders were closed, travel restrictions and lockdowns were imposed.

The first coronavirus case was reported on March 10, 2020 in our country (4). The health authorities also implemented strict restrictions such as self-isolation, the use of masks, and home quarantine to prevent the spread of the disease.

The disease-related isolation resulted in loneliness, fear of death, and depression. These restrictions also caused the separation of families and partners, and unemployment with loss of income, as observed in previous outbreaks $(5,6)$. Rajkumar (7) reported increased anxiety, depression (experienced by $16-28 \%$ of the population), and selfreported stress (shared by $8 \%$ of the population) as the most common mental reactions during the COVID-19 pandemic.

Sexuality is a significant part of a couple's life, which may affect mental health (8). Due to the pandemic, self-isolation and social distance have negatively affected sexual life (9). However, there is still a lack of knowledge regarding the effect of pandemic and decreased income on female sexual life.

This study aimed to evaluate women's sexual behavior during the COVID-19 pandemic in our country.

\section{Materials and Methods}

This prospective, observational study was conducted in a tertiary referral hospital between June 27 and July 27 , 2020. The approval for the study was obtained from the Ministry of Health (2020.05.25T22.02.17). Besides, ethical approval was obtained from the local ethics committee of our hospital (University of Health Sciences Turkey, İstanbul Bağcllar Training and Research Hospital Clinical Research
Ethics Committee, approval number: 2020.07.2.08.109). The study was conducted in accordance with the Declaration of Helsinki and its later amendments. All participants were included after obtaining informed consent.

A questionnaire consisting of 13 questions regarding the sexual life during the COVID-19 pandemic was applied to 169 women aged $18-45$ years, who were admitted to the gynecology outpatient clinic due to routine controls. The questionnaires from the recent studies of Jacob et al. (10) from the UK and Li et al. (11) from China on the same topic were taken as examples. Women with regular and active sexual life were included. The questions about patients' basic characteristics, such as age, education, marital status, monthly income, systemic disease, drug addiction, alcohol consumption, and smoking, were asked. The questions evaluating sexual behavior such as the relationship with partner, sexual desire, frequency of intercourse, sexual satisfaction, and fertility desire were then recorded. The exclusion criteria were as follows; not having a regular partner, COVID-19 positivity, history of cancer, endometriosis, pelvic pain, incontinence, menopause, vaginal atrophy, severe systemic disease (diabetes, hypertension, and coronary artery disease), mental disorders, and pregnancy or lactation. Twentynine patients who were not compatible with the inclusion criteria were excluded. One hundred forty women were included in the study. Women were divided into two groups as those above and below the monthly hunger limit. At the time of the study, the monthly hunger limit per person in our country was 2.500 Turkish Liras (TL). The participants in the increased income group were excluded since there were only three women in this group, which was insufficient for statistical comparisons.

The sample size was calculated via the G power program, version 3.1. The effect size to determine the sexual activity of the study group was determined as 0.26 . The analysis with a $1-\beta$ of 0,8 and alpha error of 0.05 revealed that 117 patients were required.

\section{Statistical Analysis}

Statistical analyses were performed with the Statistical Package for the Social Sciences (SPSS) 20 program (IBM Corp, Armonk, NY, USA). In addition to the descriptive statistical methods (mean, standard deviation), the Pearson's chi-square test and Fisher's Exact test were used to compare categorical variables. A p-value of $<0.05$ was considered statistically significant. 


\section{Results}

The mean age of the participants was $32.9 \pm 7.74$ years (18$45)$. The mean age of their spouse was $36.73 \pm 8.54$ years. $93.6 \%$ of the participants were married, and $52.1 \%$ were primary school graduates. $49.3 \%$ of the participants had a monthly income below 2.500 TL. Regarding the monthly income, $84(60 \%)$ patients had a decrease, $53(37.9 \%)$ of them remained stable, and only $3(2.1 \%)$ of them had an increase during the pandemic. The rate of living with their parents was $18.6 \%$. Demographic features and the economic status of all participants were shown in Table 1.

$16.4 \%$ of participants had a worsened relationship with their partner during the COVID-19 pandemic. Sexual desire of the participants was decreased by $32.9 \%$ and remained the same in $58.6 \%$ of the participants. The frequency of sexual intercourse was the same in $55.7 \%$ of women, decreased in $33.6 \%$ of women, and increased in $10.7 \%$ of women. During the COVID-19 pandemic, sexual satisfaction decreased in $27.9 \%$ of participants. $25.7 \%$ of respondents reported a reduced fertility desire (Table 2).

The study groups were divided into the stable and decreased income groups after excluding three patients with an increased income due to a low number of participants. No statistically significant difference was found between the groups regarding the relationship with a partner, frequency of sexual intercourse, and fertility desire ( $p>0.05)$. However, a statistically significant difference was found between the decrease in sexual desire rates. A higher rate of $40.5 \%$ was observed in the decreased group than in the stable income group with $22.7 \%$ ( $\mathrm{p}=0.03)$.

A statistically significant difference was found in terms of sexual satisfaction rates between the income level groups. The rate of increase in sexual satisfaction in those with a decreased income was found to be higher than in those with a stable income ( $10.7 \%$ vs. 0 , respectively, $\mathrm{p}=0.04$ ) (Table 3 ).

\section{Discussion}

In this study, relationship with partner, sexual desire, frequency of intercourse, sexual satisfaction, and fertility desire remained stable in most participants during the COVID-19 pandemic. However, considering the monthly income and evaluation of sexual life, sexual desire was less in the decreased income group. On the contrary, there was an increase in sexual satisfaction in the decreased income group. This may be associated with increased time spent together, less work stress, and less social or family obligations.
Table 1. Demographic characteristics of women $(n=140)$

\begin{tabular}{|c|c|c|}
\hline Characteristics & \multicolumn{2}{|c|}{ Mean \pm SD } \\
\hline Age (years) & \multicolumn{2}{|c|}{$32.90 \pm 7.74$} \\
\hline \multirow[t]{2}{*}{ Partner age (years) } & \multicolumn{2}{|c|}{$36.73 \pm 8.54$} \\
\hline & $\mathbf{n}$ & $\%$ \\
\hline \multicolumn{3}{|l|}{ Marital status } \\
\hline Single/divorced/widowed & 9 & 6.4 \\
\hline Married & 131 & 93.6 \\
\hline \multicolumn{3}{|l|}{ Education level } \\
\hline Illiterate & 2 & 1.4 \\
\hline Primary school graduate & 73 & 52.1 \\
\hline High school graduate & 36 & 25.7 \\
\hline Postgraduate & 29 & 20.7 \\
\hline \multicolumn{3}{|l|}{ Per capita monthly income } \\
\hline$<2.500 \mathrm{TL} /$ month & 69 & 49.3 \\
\hline$>2.500 \mathrm{TL} /$ month & 71 & 50.7 \\
\hline \multicolumn{3}{|l|}{ Monthly income } \\
\hline Increased & 3 & 2.1 \\
\hline Reduced & 84 & 60 \\
\hline Remained the same & 53 & 37.9 \\
\hline \multicolumn{3}{|l|}{ Living with parents } \\
\hline Yes & 26 & 18.6 \\
\hline No & 114 & 81.4 \\
\hline \multicolumn{3}{|l|}{ Smoking } \\
\hline Yes & 35 & 25 \\
\hline No & & 75 \\
\hline \multicolumn{3}{|c|}{ Drug and alcohol consumption } \\
\hline Yes & 2 & 1.43 \\
\hline No & 138 & 98.57 \\
\hline
\end{tabular}

TL: Turkish Lira, SD: Standard deviation

The social restrictions, decreased monthly income, fear of unemployment, loneliness, and fear of death increased stress, anxiety, and depression during the pandemic. Hamilton and Meston (12) have reported that prolonged exposure to the aforementioned stress reduces sexual desire.

Several publications have been reported on the effect of the COVID-19 pandemic on sexual functions. Karsiyakali et al. (13) designed a study comprising 1.356 men and women living in large and small cities. They concluded a decreased rate of sexual desire and intercourse frequency but an increased rate of masturbation during the COVID-19 pandemic. The decreased rates were more prominent in couples living in large cities than those living in small cities. These results are supposed to be associated with the population density and the high number of COVID-19 cases in large cities (13). Ibarra et al. (14) also emphasized 
Table 2. Distributions related to sexual behaviors

\begin{tabular}{lll} 
& $\mathbf{n}$ & $\%$ \\
\hline Relationship with partner & 26 & 18.6 \\
\hline Good & 23 & 16.4 \\
Poor & 91 & 65 \\
General & & \\
Sexual desire & 12 & 8.6 \\
Increased & 46 & 32.9 \\
Reduced & 82 & 58.6 \\
Remained the same & & \\
Frequency of sexual intercourse & 15 & 10.7 \\
Increased & 47 & 33.6 \\
Reduced & 78 & 55.7 \\
Remained the same & & \\
Sexual satisfaction & 10 & 7.1 \\
Increased & 39 & 27.9 \\
Reduced & 91 & 65 \\
Remained the same & & \\
Fertility desire & 26 & 18.6 \\
Increased & 36 & 25.7 \\
Reduced & 78 & 55.7 \\
Remained the same & & \\
\hline
\end{tabular}

that COVID-19 negatively affected sexual behaviors. A study conducted with 868 sexually active people in the United Kingdom reported worsening sexual desire, especially in older and single people (10). In another study conducted in China, $37 \%$ of the participants showed a decrease in the frequency of sexual intercourse during the pandemic. In this study, age, relationship status with the partner, and sexual desire were found to be closely related to the frequency of intercourse (11).

In a study evaluating sexual functions before and after quarantine during the COVID-19 pandemic, in which 764 women from Poland participated, a statistically significant decrease was observed in the female sexual function index (FSFI) scores. The reduction was higher in unemployed women (15). A study from Italy also found that total FSFI scores of women of reproductive age decreased during the COVID-19 pandemic. Besides, being unable to work at home, having postgraduates, and having multiparity are reported as independent risk factors for a low FSFI score (3).

On the contrary, Hall et al. (16) reported that women's sexual activity increased significantly during intense stress. In another study, Yuksel and Ozgor (17) reported that menstrual irregularities and desire for sexual intercourse
Table 3. Comparison of the sexual behavior of the participants whose income level did not change with those whose income level decreased during the COVID-19 pandemic

\begin{tabular}{clll}
$\begin{array}{l}\text { Decreased } \\
\text { income } \\
(\mathrm{n}=84)\end{array}$ & $\begin{array}{l}\text { Stable } \\
\text { income } \\
(\mathrm{n}=53)\end{array}$ & $\begin{array}{l}\text { Test } \\
\text { statistics }\end{array}$ & $\mathrm{p}$ \\
\cline { 1 - 2 } $\mathrm{n} \quad \%$ & $\mathrm{n} \quad \%$ &
\end{tabular}

\begin{tabular}{|c|c|c|c|c|c|c|}
\hline \multicolumn{7}{|c|}{ Relationship with partner } \\
\hline Average & 52 & 61.9 & 37 & 69.8 & $\chi^{2}=2.809$ & 0.246 \\
\hline Good & 19 & 22.6 & 6 & 11.3 & & \\
\hline Poor & 13 & 15.5 & 10 & 18.9 & & \\
\hline \multicolumn{7}{|c|}{ Sexual desire } \\
\hline Increased & 9 & 10.7 & 3 & 5.7 & & \\
\hline Reduced & 34 & 40.5 & 12 & 22.7 & $\chi^{2}=6.978$ & 0.031 \\
\hline $\begin{array}{l}\text { Remained } \\
\text { the same }\end{array}$ & 41 & 48.8 & 38 & 71.7 & & \\
\hline \multicolumn{7}{|c|}{ Frequency of sexual intercourse } \\
\hline Increased & 11 & 13.1 & 3 & 5.7 & $\chi^{2}=5.191$ & 0.075 \\
\hline Reduced & 32 & 38.1 & 14 & 26.4 & & \\
\hline $\begin{array}{l}\text { Remained } \\
\text { the same }\end{array}$ & 41 & 48.8 & 36 & 67.9 & & \\
\hline \multicolumn{7}{|c|}{ Sexual satisfaction } \\
\hline Increased & 9 & 10.7 & 0 & 0 & $\chi^{2}=6.283$ & 0.043 \\
\hline Reduced & 24 & 28.6 & 15 & 28.3 & & \\
\hline $\begin{array}{l}\text { Remained } \\
\text { the same }\end{array}$ & 51 & 60.7 & 38 & 71.7 & & \\
\hline \multicolumn{7}{|c|}{ Fertility desire } \\
\hline Increased & 13 & 15.5 & 11 & 20.8 & $\chi^{2}=0.954$ & 0.621 \\
\hline Reduced & 24 & 28.6 & 12 & 22.6 & & \\
\hline $\begin{array}{l}\text { Remained } \\
\text { the same }\end{array}$ & 47 & 56 & 30 & 56.6 & & \\
\hline
\end{tabular}

increased during the pandemic and total FSFI scores were higher. Micelli et al. (18) found that the frequency of sexual intercourse did not decrease in the vast majority of Italians (66.4\%) before and during the pandemic (18). Our results were also compatible with this study. However, more than a third of them decided to postpone having children. These results could be associated with economic instability and fear of the impact of COVID-19 infection on pregnancy outcomes.

Although the relationship between unemployment and sexual activity has not been clarified, unemployment is associated with an increased risk of depression (19). The unemployment and low income caused by the pandemic also support our results.

Controversial results have been reported regarding the effect of the COVID-19 pandemic on sexual functions (15- 
19). Although our results are consistent with the decrease in sexual desire in the decreased income group, we may postulate that increased sexual satisfaction could be related to spending more time with the couples at home. The different study results could be explained by the different reactions of the countries to stress management.

\section{Study Limitations}

The present study has some limitations. The number of participants in the study group was relatively small. The strength of or study could be attributed to face-toface interview approach that could lead to more reliable answers. Although the FSFI questionnaire seems to be an objective method to evaluate female sexual dysfunction, the entire parameters of FSFI were not compatible with our study design.

\section{Conclusion}

Sexuality is a complex phenomenon affected by a variety of factors. Acute stress caused by the COVID-19 pandemic has negatively affected the quality of life and sexuality. In our study, the decreased income level was associated with decreased sexual desire in women. The truth is that there are still many unknowns regarding both COVID-19 and sexuality. Therefore, larger prospective studies are needed.

\section{Ethics}

Ethics Committee Approval: Ethical approval was obtained from the local ethics committee of our hospital (University of Health Sciences Turkey, İstanbul Bağcılar Training and Research Hospital Clinical Research Ethics Committee, approval number: 2020.07.2.08.109).

Informed Consent: All participants were included after obtaining informed consent.

Peer-review: Externally and internally peer-reviewed.

\section{Authorship Contributions}

Concept: E.E.K., Design: E.E.K., Data Collection or Processing: Ö.Y.A., Ö.K.A., Analysis or Interpretation: T.K., H.G., Drafting Manuscript: E.E.K., Ö.K.A., Ö.Y.A., Critical Revision of Manuscript: T.K., H.G., Final Approval and Accountability: E.E.K., Ö.K.A., Ö.Y.A., T.K., H.G.

Conflict of Interest: No conflict of interest was declared by the authors.

Financial Disclosure: The author declared that this study has received no financial support.

\section{References}

1. World Health Organization (2020). Coronavirus disease (COVID-19) Last Accessed Date: 12.10.2020. Available from: https://www.who.int/ emergencies/diseases/novel-coronavirus-2019? adgroupsurvey= adgro upsurvey\}\&gclid=CjwKCAjwmeiIBhA6EiwA-uaeFfsV25bOK5FtIQvshTu MUxK7znOarF9JP9D9Aiuq7XNPkPhtSRhZRoC50wQAvD_BwE.

2. Liao X, Wang B, Kang Y. Novel coronavirus infection during the 2019-2020 epidemic: preparing intensive care units- the experience in Sichuan Province, China. Intensive Care Med 2020;46(2):357360.

3. Schiavi MC, Spina V, Zullo MA, Colagiovanni V, Luffarelli P, Rago $\mathrm{R}$, et al. Love in the time of COVID-19: sexual function and quality of life analysis during the social distancing measures in a group of Italian reproductive-age woman. J Sex Med 2020;17(8):1407-1413.

4. Ministry of Health of the Republic of Turkey. Available from: https://covid19.saglik.gov.tr/TR-66471/i.html.

5. Duan L, Zhu G. Psychological interventions for people affected by the COVID-19 epidemic. Lancet Psychiatry 2020;7(4):300-302.

6. BaoY,SunY,MengS, ShiJ,LuL.2019-nCoVepidemic:address mental health care to empower society. Lancet 2020;395(10224):e37-e38. doi: 10.1016/S0140-6736(20)30309-3.

7. Rajkumar RP. COVID-19 and mental health: A review of the existing literature. Asian J Psychiatr 2020;52:102066.

8. Ventriglio A, Bhugra, D. Sexuality in the 21st century: Sexual fludity. East Asian Arch Psychiatry 2019;29(1):30-34.

9. Baldwin DS. Depression and sexual dysfunction. Br Med Bull 2001;57(1):81-99.

10. Jacob L, Smith L, Butler L, Barnett Y, Grabovac I, McDermott D, et al. Challenges in the practice of sexual medicine in the time of COVID-19 in the United Kingdom. J Sex Med 2020;17(7):1229-1236.

11. Li W, Li G, Xin C, Wang Y, Yang S. Challenges in the practice of sexual medicine in the time of COVID-19 in China. J Sex Med 2020;17(7):1225-1228.

12. Hamilton LD, Meston CM. Chronic stress and sexual function in women. J Sex Med 2013;10(10):2443-2454

13. Karsiyakali N, Sahin Y, Ates HA, Okucu E, Karabay E. Evaluation of the sexual functioning of individuals living in Turkey during the COVID-19 pandemic: an internet-based nationwide survey study. Sex Med 2020 Oct 26;9(1):100279.

14. Ibarra FP, Mehrad M, Di Mauro M, Godoy MFP, Cruz EG, Nilforoushzadeh MA, et al. Impact of the COVID-19 pandemic on the sexual behavior of the population. The vision of the east and the west. Int Braz J Urol 2020;46(Suppl 1):104-112.

15. Fuchs A, Matonóg A, Pilarska J, Sieradzka P, Szul M, Czuba B, et al. The impact of COVID-19 on female sexual health. Int J Environ Res Public Health 2020;17(19):7152.

16. Hall KS, Kusunoki Y, Gatny H, Barber J. Stress symptoms and frequency of sexual intercourse among young women. J Sex Med 2014;11(8):1982-1990.

17. Yuksel B, Ozgor F. Effect of the COVID-19 pandemic on female sexual behavior. Int J Gynaecol Obstet 2020;150(1):98-102.

18. Micelli E, Cito G, Cocci A, Polloni G, Russo GI, Minervini A, et al. Desire for parenthood at the time of COVID-19 pandemic: an insight into the Italian situation. J Psychosom Obstet Gynaecol 2020;41(3):183-190.

19. Zuelke AE, Luck T, Schroeter ML, Witte AV, Hinz A, Engel C, et al. The association between unemployment and depression-results from the population-based LIFE-adult-study. J Affect Disord 2018;235:399-406 